\title{
Грануломатоза на Wegener: човекът зад епонима
}

\author{
доц. д-р Добрин Паскалев \\ Медицински университет „Проф. д-р П. Стоянов“ - Варна
}

$\mathrm{E}$ поним на грануломатозно некротизиращо възпаление, засягащо респираторния тракт, съпроводено с некротизиращ васкулит и гломерулонефрит (ГН). През 1954 г. са предложени диагностични критерии за заболяването, които включват: некротизиращо грануломатозно възпаление на горните и/или долните дихателни пьтища; системен или фокален некротизиращ васкулит и некротизиращ полулунен ГН. Важен момент в патогенетичен и диагностичен аспект е установяване на антинеутрофилни антитела, насочени към цитоплазмени антигени ( ANCA). Кьм заболяването е установена и генетична предиспозиция (HLAB8; HLA-B2; HLA-DR2) [1, 3, 4, 5]. В България първите 2 случая са описани през 1970 г. [1]. Заболяването носи името на немския патолог Friedrich Wegener $(1907$ - 1990) [3]. От 2011 г. епонимът е заменен с наименованието „грануломатоза с полиангиит".
Friedrich Wegener e роден на 7.04.1907 г. в градчето Фарел, Долна Саксония, в семейството на Friedrich Wegener, хирург, и Thyra Cecilia, учителка по гимнастика, от шведски произход. След получаване на гимназиално образование (1926) следва медицина в

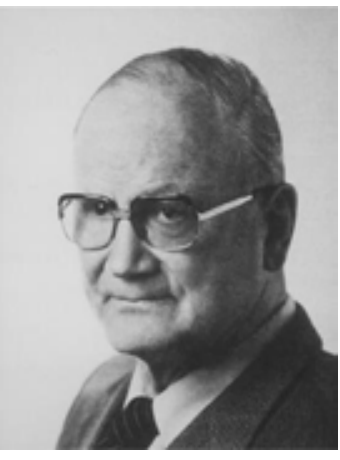

Friedrich Wegener Мюнхен и се промовира в Кил (1932). По време на студентството си се изявява като спортист и състезател по хвърляне на топка (Schleuderballwurf), лекоатлетическа дисциплина в Долна Саксония, и през 1931 г. печели шампионска титла. Като студент се увлича от патология и след завършването си започва работа в Катедрата по патология на университета в Кил под ръководството на Leonhard Jores (1866 - 1935), известен с работите си в областта на съдовата патология. От 1934 г. ръководството на катедрата поема Martin Staemmler (1890 - 1974), поддръжник на ,расовата чистота u хигиена" по време на Нацисткия режим в Германия. Като асистент Wegener води курсове по секционна техника, специална патология и хистология за студенти по стоматология $[7,8]$. През 1936 г. на 29-тата конференция на Немското дружество по патология Wegener представя три случая с неясна диагноза. Касае се за млади 
пациенти (двама мъже на 38 години, респ. 36 г. и жена на 38 г.), чието заболяване се изявява „след 4-7-месечни оплаквания с клинична картина на сепсис и температура около $39.5^{\circ} \mathrm{C}$, с негативни при посявка хемокултури, силно ускорена СУЕ, многократно отрииателни проби за Waaler Rose, взети от кръв и ликвор, $u$ тежко изявена анемия; аглутационните проби за тиф, паратиф, Bang (бруцелоза - б.м.), Flexner (дизентерия - б.м.) и Weil (лептоспироза - б.м) - са негативни. Заболяването започва с ринит, последван от стоматит, фарингит и трахеит. В основата на заболяването стои патологичен прочес в носа с образуване на зловонна коричка. В първите два случая се достига до перфорачия на носната преграда. В своето развитие болестта води до бъбречно засягане с поява на белтьк в урината, а в седимента - еритроцити, левкоцитти, хиалинни и гранулирани цилиндри. Липсва повишено артериално налягане. В първия случай азотните тела са завишени с поява на уремия, а в третия случай е налице пълна анурия “. Патологоанатомично се установяват инфарктоподобни промени с кавернозен разпад в белите дробове и големи пъстри бъбреци с белези на кървене. Макроскопската картина наподобява тази при периартериитис нодоза в различни органи, като в бъбреците находката е както при огнищен гломерулонефрит. В заключение Wegener обобщава, че „клиничното протичане и сходството в патологоанатомичните промени в трите случая дава основания да се обособи малко познато до този момент заболяване, при което са налице: (1) септично състояние, (2) тежко некротичногрануломатозно възпаление на вътрешния нос, съчетано с ангажиране на гълтача и гракляна; (3) промени в бъбреците в смисъла на токсичен огнищен гломерулонефрит и (4) генерализиран артрит, протичаш с картината на периартериитис нодоза“" [6].

По време на Втората световна война (1939 - 1945) Wegener е едновременно военен и цивилен патолог в Лодз, където месечно се извършват 50-100 аутопсии. През 1944 г. той се разболява от дифтерия и се възстановява около година, след което отново е в резерва на Вермахта като военен хирург. През 1945 г. за кратко е задържан в американски плен и след освобождаването си работи в селското стопанство до 1947 г. От 1948 г. той се завръща на медицинското поприще, първоначално като научен асистент, а след това като ръководител на Института по патология към университета в Любек. Тук Wegener развива успешна изследователска и преподавателска дейност, като проучва метастатичната чернодробна болест, острата мастна дистрофия на хепара при бременни, мастните емболии и хепатотоксичния ефект на кофеина и теофилина. С особена популярност се ползват неговите редовни патологоанатомични семинари. Почитан като изявен преподавател, той се пенсионира през месец март 1970 г., а в негова чест студентите му организират факелно шествие $[7,8]$.

По-късно F. Wegener публикува обширна статия по проблема (1939). През 1954 г. G. Godman и J. Churg описват нови случаи и наричат заболяването „грануломатоза на Wegener“ (Wegener's granulomatosis) [3].

F. Wegener доживява да види първите успехи от лечението с циклофосфамид на заболяването, което сам е описал като неизбежно фатално. В последните години от живота си той е свидетел на откриването на ANCA като маркер на болестта. След 1986 г. Wegener е редовен участник на различни научни форуми, посветени на васкулитите, а през 1990 г. пише своята последна публикация.

Friedrich Wegener умира на 9.07.1990 г. в Любек от мозъчен инсулт $[7,8]$.

След 2006 г. стават известни някои подробности относно връзки на Wegener с националсоциалистически партийни структури. Известно е, че неговият ръководител M. Staemmler е убеден привърженик на националсоциализма и на „расовата хигиена“, а брат му Paul Wegener e гаулайтер в северозападните райони на Германия. Това не е изключение от трудната ситуация, в която попадат редица учени и интелектуалци по време на режима на Хитлер в Германия. Към момента липсват сигурни доказателства за извършени военновременни престъпления (експерименти с хора) от F. Wegener [7, 8, 9], но е предложена замяна на епонима с наименованието ,грануломатоза с полиангиит“ (Granulomatosis with polyangiitis).

През 2004 г. в интересно и задълбочено проучване Harald Feldmann, оториноларинголог, достига до извода, че видният немски физик и открива- 
тел на електромагнитните вълни Heinrich Hertz (1857 - 1894) е страдал и е починал от „грануломатоза на Wegener“. Неговият последен забележителен труд „Принципи на механиката“ е довършен по време на заболяването, само месеци преди смъртта му [2].

\section{Литература:}

1. Паскалев Д., Д. Петкова, В. Икономов. Бъбреци и бял дроб - заедно в болестта. In Spiro 2009; $2(3): 5-8$.

2. Feldmann H. Ein historischer Fall von Wegenerscher Granulomatose: der Physiker und Entdecker der elektromagnetischen Wellen Heinrich Hertz. Laryngo-Rhino-Otol 2005; 84(6):426-431.

3. Godman GC, J Churg. Wegener's granulomatosis: pathology and review of the literature. AMA Arch Pathol 1954; 58(6):533-53.

4. Jennette J, RJ Falk. Kidney involvement in systemic vasculitis, in: A.Greenberg (ed), Primer on Kidney Diseases, Sander Elsevier, Philadelphia, 2009, 200-207.

5. Watorek E, M Boratyńska, M Klinger. Wegener's granulomatosis-autoimmunity to neutrophil proteinase 3. Arch Immunol Ther Exp (Warsz) 2003; 51(3):157-67.

6. Wegener F. Ueber generalisierte, septische Gefaesserkrankungen, Verhandl. Deutsch Pathol Gess 1936; 29:202-210.

7. Wegener F. https://de.wikipedia.org/wiki/Friedrich Wegener.

8. Woywodt A, M Haubitz, H Haller, EL Matteson. Wegener's granulomatosis. Lancet 2006; 367(9519):1362-6.

9. Woywodt A, EL Matteson. Wegener's granulomatosis--probing the untold past of the man behind the eponym. Rheumatology 2006; 45(10):1303-6. 